\title{
TRANSCULTURALITY THROUGH INDUSTRIAL SPACE: CEMBENGAN AT THE COLOMADU SUGAR FACTORY
}

\author{
Ade Ariyani Sari Fajarwati ${ }^{1 *}$; Lilawati Kurnia ${ }^{2}$ \\ ${ }^{1}$ Interior Design Department, School of Design, Bina Nusantara University \\ Jl. K. H. Syahdan, No. 9, Kemanggisan, Palmerah, Jakarta 11480, Indonesia \\ ${ }^{2}$ Literature Department, Faculty of Humanities, Universitas Indonesia \\ J1. Prof. DR. Selo Soemardjan Kampus, Pondok Cina, Depok 16242, Indonesia \\ 1ade@binus.ac.id; ${ }^{2}$ lila@ui.ac.id
}

Received: $12^{\text {th }}$ January 2021/ Revised: $08^{\text {th }}$ February 2021/ Accepted: $15^{\text {th }}$ February 2021

How to Cite: Fajarwati, A. A. S, \& Kurnia, L. (2021). Transculturality through industrial space:

Cembengan at the Colomadu sugar factory. Humaniora, 12(1), 45-51.

https://doi.org/10.21512/humaniora.v12i1.6918

\begin{abstract}
The research aimed to explain Cembengan celebrations held at the Colomadu sugar factory, Karanganyar which was built in 1861. This celebration was held every time the factory would start milled processing sugar cane into sugar. The word "cembeng" itself came from the Chinese word "Cengbeng", which was a ritual to commemorate deceased ancestors. Cengbeng was held every April $5^{\text {th }}$ by cleaning graves and placing food and prayer tools such as incense and candles. Meanwhile, the Cembengan tradition itself as a ritual also commemorated the ancestors, but its function had turned into a ritual to start the production process at a sugar factory. This ritual was considered important so that it was carried out continuously for hundreds of years in a Javanese industrial space. This ritual was also attended by Dutch officials when it was still under the control of the Dutch East Indies. The research investigated the intersection between space, capital, and culture, which formed an 'invented tradition'. The method used was through historicity approach and analyzed the relationship between space and the formation of Cembengan tradition in the Colomadu sugar factory. The results show that the transcultural aspect no longer consults the origin but rather cultural practices that merge cultural boundaries.
\end{abstract}

Keywords: transculturality, industrial space, Cembengan, Colomadu sugar factory

\section{INTRODUCTION}

The celebration of Cembengan is a ritual tradition that occurs every year through generations in sugar factories in Java since the Dutch colonial period. This ceremony is done to signify time to harvest sugar canes as their raw material to process in sugar factories. This tradition is done by the factory and is supported by the communities surrounding the factories and has been going on for hundreds of years. The Cembengan is interpreted as a sign of gratitude, a request for safety, and hope for better production results.

Cultural acculturation is an adaptation strategy to be able to maintain the human culture in the next life. It happened to the Cembengan ceremonies in the Colomadu sugar factory and Tasikmadu sugar factory, located at Karanganyar, Central Java province. The two factories are a discussion that is interpreted as commensurate because they have similar historical relevance. Colomadu (1861) is the first sugar factory owned by the natives of Java that took place in the colonial period. This industrial space appears traditions of ritual that evolve in some sugar mills in the region of Javanese culture. The discussion on the Cembengan tradition is more focused on the Colomadu sugar factory as a reference because it is the beginning of establishing the ceremony and ritual center of the other factories.

Important values as a heritage from an industrial space such as the Colomadu sugar factory, based on several aspects are aspects of location, age, function, initial ownership, physical condition, architecture, and aspects of historical events (Nugroho et al., 2020). The Cembengan tradition has formed cultural memories 
as a series of ritual ceremonies involving owners, managers, factory workers, and the surrounding community.

Colomadu sugar factory (1861) and Tasikmadu sugar factory (1871) were founded by Mangkunegara IV, a Javanese aristocrat, ruler of the Mangkunegaran royal family in the Javanese community (Wasino, 2005). The rapidly increasing trend of the sugar industry in the world market influenced Mangkunegaran's decision to join the industry. Sugar production in the Java region was the second-largest position in the world after Cuba in the colonial period. Industrial machinery was imported from Europe to the island of Java to drive the sugar factory (Knight, 2000). The results of the production of machines that were uniform, fast, and efficient attracted investments in equipment to produce sugar in a larger and more profitable capacity.

The Mangkunegaran's closeness with the Dutch colonial as a local Javanese elite made it easier to grant a business license to an aristocrat who in the Javanese society was placed at the level of a leader who was considered taboo for trading (Birsyada et al., 2017). For the sugar business stocks, Mangkunegara IV collaborated with Major Bi Biaw Tjoan from Semarang and named the Colomadu sugar factory (Wasino, 2005). In the notes contained in the De Tjolomadoe museum, Nyi Pulungsih, the daughter of Bi Biaw Tjoan, was made a concubine by Mangkunegara IV. The business instinct of this Chinese investor was undeniably one of the determinants of the success of the sugar business carried out by a Javanese aristocrat. The sales of this factory were so successful that ten years later, the Tasikmadu sugar factory was built in 1871. The construction of the two sugar factories by Praja Mangkunegaran sparked the emergence of sugar factories on royal lands (vorstenlanden) in Surakarta and Yogyakarta. Since 1946, the sugar factories had been taken over and managed by the Indonesian government. However, the connection between Colomadu and Tasikmadu sugar factory with Praja Mangkunegaran still creates Cembengan tradition with the same ritual concept. Currently, the Cembengan ceremony at the Tasikmadu sugar factory is still ongoing, while at the Colomadu sugar factory, it is no longer implemented since the factory began adapted into a tourism center in 2018 (Ardhiati et al., 2020).

The Cembengan celebration lasts for two weeks, with ritual activities covering a series of ritual ceremonies, folk art performances, and night markets. It is started from a sacred ceremony related to salvation prayers and pilgrimages to ancestors and ending with a continuous folk party until the Cembengan celebration is closed (Pontjowolo, 1992). The people around the sugar factory recognize this tradition as a meaningful Javanese ritual, as a form of prayer for salvation and respect for their ancestors. Existing research on the Cembengan ceremony at the Colomadu sugar factory emphasizes the procedure of ritual and also its symbolic meaning. Hilmiyah Pontjowolo, a relative of
Mangkunegaran, has researched the background and procedure of the ceremony held at the Colomadu and Tasikmadu sugar factories.

Pontjowolo emphasizes this ceremony as an existing tradition with Javanese cultural customs in its ritual activities. The discussion of this research has not yet touched on the origins of traditions involving inter-ethnic Javanese, Chinese, and Dutch colonial interests. The link between the Cembengan ceremony and the myth of a Javanese woman's ghost in the Colomadu sugar factory is reviewed by Pemberton (2003). Through a photo of the Cembengan ceremony, which took place during the Mangkunegara VII era, this historian from Australia has seen how the machine used as a sugar mill was treated as a sacred object by involving the Dutch colonialists (Pemberton, 2003). The photo shows a Dutch official doing a spray on a sugar factory machine using a scoop from coconut shells in a ritual ceremony. In this research, Pemberton (2003) shows the imbalance between modern machines and the belief in myths that prevailed in Javanese society around the Colomadu sugar factory.

Another researcher, Wasino (2015), specifically discusses the Colomadu sugar factories in journals and books. This historian from Semarang has studied many discussions about the Mangkunegara Royal company's historicity through native capitalism (Wasino, 2015). He has said the Colomadu sugar factory is the first sugar factory owned by natives, as a concept of modernity that is presented in Javanese culture. In his research, the origin of the establishment of the Colomadu sugar factory as a business collaboration between indigenous capitalism and Chinese entrepreneurs is revealed, as well as regulatory support from the Netherlands. The discussion regarding the Cembengan ceremony is not an important discussion, but the historicity data compiled by Wasino can be used as a reference in this research. From the various readings of the various studies that have been carried out on the Cembengan tradition at Colomadu sugar factory's space, there are gaps in discussion to reveal the fusion of Javanese, Chinese, and Dutch behind the emergence of this tradition. Transcultural has become an important process in the formation of Cembengan, and this has not been disclosed in previous research.

The celebration of Cembengan seems to be an original tradition passed down from the Javanese people when viewed based on rituals, ceremonies, and events at the Colomadu sugar factory. However, the interplay of Javanese, Chinese, and Dutch colonial interests is thought to have influenced the creation of the Cembengan tradition. An analysis is needed by tracing the history, ritual order, and beliefs that have emerged in Javanese society to uncover the function of the Cembengan celebration for Javanese people and show Javanese, Chinese, and Dutch cultural linkages in the transcultural process. The research also reveals the meaning of acculturation at the Cembengan celebration through the community's involvement around the sugar factory in these traditional activities. 


\section{METHODS}

The research applies a qualitative descriptive method. To collect data and information, the researchers conduct several types of techniques, such as collecting literature data in the form of books, journals, newspaper articles, and old photographs related to the Cembengan tradition, site observations to the industrial space of sugar factory in Java, and interviews. After collecting data, the researchers make an analysis to make results and conclusions.

\section{RESULTS AND DISCUSSIONS}

The Cembengan tradition signifies the sugarcane milling season which is carried out with a series of ceremonies over a period of two weeks. These ritual events are related to activities at the sugar factory that begins with a pilgrimage to the Colomadu sugar factory founders' graves. The pilgrimage takes place at a special cemetery for the king of Mangkunegaran descent named Astana Giri Layu, which is located on the slopes of Mount Lawu (Fauzi, Saddhono, \& Rakhmawati, 2020). The shape of Mangkunegara IV's tomb is European style, which marks the transcultural process that occurred in Javanese culture, which is influenced by colonial culture. It was built during the Mangkunegara VII era by a Dutch architecture named Thomas Karsten. The pilgrimage ritual is carried out by the leaders and administrators of the sugar factory not only to Girilayu but also to the grave of Nyi Pulungsih, the concubine of Mangkunegara IV, which is located adjacent to sugar factory Colomadu (Fauzi, Saddhono, \& Rakhmawati, 2020). Nyi Pulungsih's (Miss Bhe) role is considered important in establishing the sugar factory, so placing the tomb of a concubine of Chinese descent became part of the ritual that must be done.

The Cembengan tradition takes place once a year and is carried out right before the sugar cane milling in a sugar factory happens. After that the pilgrimage, the ritual is continued with the Manten Tebu ceremony, which is done by plucking the first two cane stalks that are harvested and then put into the grinding machine for the first time. This pair of sugar cane is considered as temanten (bridegroom) and is treated like manten (wedding ceremony), complete with a midodareni (bridal shower) for the temanten sugar cane pair, ending with a wedding reception. The sweet sugar-producing stalks are dressed and paraded as if to welcome a real bridegroom in Javanese culture (Pontjowolo, 1992).

In the series of ceremonies, a milling ritual is also done by giving sajen (offerings) to milling machines (Fauzi, Saddono, \& Rakhmawati, 2019). A number of sajens are delivered and placed on sugar factory machines, the shape of which is similar to the offering ceremony to Dewi Sri (the goddess of rice, the staple food of Javanese people). The Cembengan ceremony, which takes place in an industrial space owned by a Javanese aristocrat, is a series of rituals that seem to be Javanese origin culture. However, upon deeper analysis, it appears that this is transcultural of Javanese, Chinese, and European cultures formed from the interest capitalization of the sugar industry. Before the presence of sugar investments, land in Java was dominated by rice as a staple food source. However, since the emergence of sugar industries in Java, local and colonial investors have planted the sugarcane fields to support the supply of raw materials for the sugar factory.

The form of the sajen consists of seven buffalo or cow heads (Figure 1), while the meat is cooked as a dish for guests and factory workers. Other offerings include food, textiles, and a pair of kembar mayang (symbolic decoration). All offerings are arranged in Javanese cultural formations, from coconut leaves as a container to other offering tools (Rosanawati, 2018). Sajen is also offered to the statue of Mangkunegara IV, which is located across the Colomadu sugar factory, and tapa bisu (staying silent during the activity).

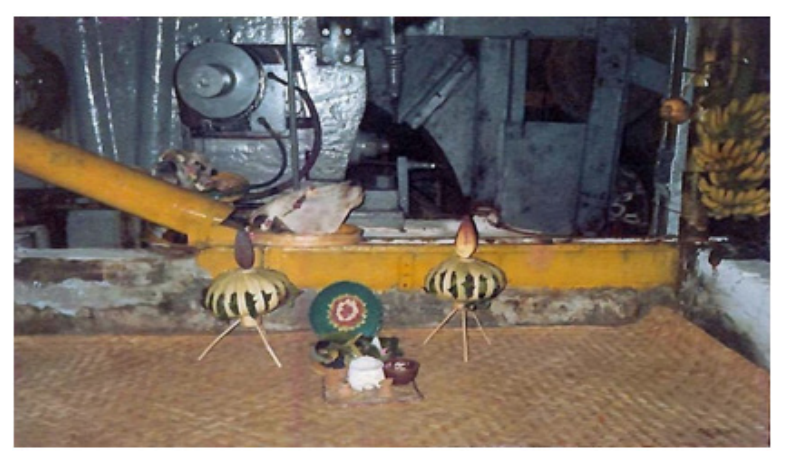

Figure 1 Cow Head for Cembengan Offering in Sugarcane Milling Machines (Source: Pontjowolo, 1992)

The main ritual event ends with shadow puppet shows, art performances, and a night market. These activities attract the surrounding community as spectators and enjoy the celebration. Capital value plays an important role in the sugar industry for Javanese aristocrats, Chinese investors, and Dutch authorities. As the driving force for the Colomadu sugar factory, the Javanese people need to be physically and spiritually balanced through the Cembengan tradition after taking care of the sugar plantations and factories for a year.

Initially, the Cembengan is done by the Colomadu and Tasikmadu sugar factory workers to ask for safety and good production results (Fauzi, Saddhono, \& Rakhmawati, 2019). Over time, it has become a hereditary tradition that turns into a folk party for the people around the sugar factory. This night market is also space for sugarcane farmers to spend the money they harvest so that the economy's wheels continue to spin. The Cembengan becomes an activity that the surrounding community eagerly awaits with a series of ritual ceremonies that are believed to affect the life of the sugar factory. Some 
researchers say that the word Cembengan comes from the Chinese tradition of Cing Bing and later becomes Ceng Beng from Chinese, which means a pilgrimage to ancestral graves (Rosanawati, 2018).

The milled salute ritual is carried out in all sugar factories in Java using different terms based on the culture of each region. At the Cepiring sugar factory, this ceremony is called Wiwit; in Kalibogo sugar factory, Purwokerto, it is called the term Partaian (from the word party) that related to the factory founder being British; in Banjarratna sugar factory, which has now turned into a rest area in Brebes, this ritual is called Bancakan; and Rendeng sugar factory, Kudus, with the term Nggantingi, and so on (Pontjowolo, 1992). The principles of the celebration, which is carried out in each sugar factory, have similarities in their ceremonial procedures. The goal is to ask the natural authorities for safety and to be given a smooth operation in the process of sugar cane milling to support sugar production. Mangkunegaran's economic progress is based on a Javanese aristocracy rooted in Javanese mysticism (Birsyada et al., 2017).

The celebration of the Cembengan customs is held every year around April-May. The term Cembengan itself becomes a big question as to why that is its name. The event that applies to the Cembengan ceremony is similar to the Chinese tradition of the Cing Bing ceremony, which is done every fifth of April by making a pilgrimage. The Chinese community in Indonesia even believes that this tradition is related to their sustenance for a year, so they try hard to carry out the pilgrimage for ancestral graves every Ceng Beng celebration. This is in line with the core ceremony of the Cembengan celebration, which begins with Nyekar (Javanese pilgrimage), a visit to the tombs of the Mangkunegaran kings, and also the tomb of Nyi Pulungsih. This pilgrimage must be carried out, especially sugar factory administrators and factory officials, with the ultimate goal of the smooth operation of the process of milling sugarcane into sugar.

Transcultural processes that occur in this industrial space are influenced by Chinese and European culture that has an interest in the sugar industry capitalization. During the colonial period, the Colomadu sugar factory administrators were occupied by Dutch people who were considered to be able to run a tidier and more professional administration. In the ritual, the administrator and factory employees who were raised in the European tradition with a more modern mind were also involved in traditional rituals to show colonial support for Javanese culture. They needed to do this to maintain relations with the local Javanese elites and maintain colonial power through the symbolic capital contained in the sugar factory.

When sugarcane was milled, farmers who were dominated by Javanese ethnicity also received money from the sugar cane harvest to supply the sugar factory. An increase in the economy made people need markets for shopping and entertainment. The existence of the night market in the series of events is a means of meeting these needs. Merchants from outside the
Colomadu area gather to offer their products, while children receive entertainment from temporary night market games in the form of carousels, ombak banyu (extreme carousel powered by human hands) as well as art exhibitions in the form of folk dances and wayang kulit (shadow puppet shows) at the Colomadu sugar factory (Sawega, 2000). The wayang kulit's story always presented the Sri Mulih, which is a sign for the Ruwatan event (reject reinforcements).

The long series of rituals at the Colomadu sugar factory showcase offerings and arts that refer to Javanese cultural traditions. However, behind this ritual, there is a local content of Chinese ethnicity that is immersed in the life of the community around the Colomadu sugar factory. The factory that previously has the impression of being haunted, for a moment, becomes lively, and there is a connection between factory workers and the surrounding community.

The Cembengan tradition is originally just a ceremony carried out by workers in the sugar factory, but it turns into a celebration for the community around the factory (Trimerani, 2020). The activities of the Cembengan tradition are always carried out and financed by sugar factories. Through an interview with Mr. Suharso (71 years old), a former employee at Colomadu sugar factory, it is said that all activities to make offerings and ceremonies at the Cembengan celebration receive a separate fund allocation which is budgeted annually by the Colomadu sugar factory company. Although it is quite expensive to perform wayang kulit shows and sajen in the form of buffalo or cow heads as equipment for Ruwatan, it is still carried out. When a factory does not perform that ritual, the employee's work ethic decreases, and it can have an impact on work disasters. Working in a sugar factory uses more feelings, so the mental condition must be in prime condition to support optimal production.

The Chinese influence turns out to be very influential in the process of running the Colomadu sugar factory. In the early days of the emergence of the sugar industry in Java, only Chinese people obtained investment permits to do sugar business apart from European entrepreneurs. The sugar business was dominated by Chinese conglomerates on the coast of the island of Java (Knight \& Brown, 2016). The involvement of Major Bi Biauw Tjoan and Nyi Pulungsih as investors and at the same time as relatives of Mangkunegara IV, who is ethnic Chinese, influences the policies carried out by this Javanese capitalist. The term Mayor in the colonial period was not a military position, but rather the Dutch term for the Chinese who were rich and had a strong influence in business. Bi Biauw Tjoan's financial strength plays a role as Mangkunegara IV's initial capital to establish a sugar factory.

The ability to process sugar is mostly controlled by the Chinese ethnics who are known to be tenacious, and their energy is very much needed by the Mangkunegaran royal family. In ancient times, the knowledge of cooking sugar was only owned by the Chinese, and they were paid high fees for special 
abilities that were kept secret and had not been understood by the Javanese society (Pontjowolo, 1992). They were imported from Semarang and Kudus (north coast of Java), who present with their families in the Surakarta area every time the milling season arrives. Wasino (2008) has noted that the population in the Colomadu area shows a significant increase in Chinese ethnicity after the sugar factory is established. They form a special settlement to get closer to the sugar processing workroom.

The presence of Chinese ethnicity in the Mangkunegaran kingdom area also impacts the process of acculturation with Javanese ethnicity in the environment. Mangkunegaran's expertise in maintaining good relations with ethnic Chinese and Dutch colonial for economic interests has been going on since before the Mangkunegara IV period. The Chinese communities, as well as the Javanese, have a habit of respecting and visiting ancestral graves, especially before important events happen. For the Chinese ethnic, the annual Ceng Beng pilgrimage ritual applies, which is similar to the Nyadran ritual performed by the Javanese people nearing the fasting month before Bakdan (Javanese big day celebration). This makes it easy for Ceng Beng to be accepted by Javanese culture who shares similar beliefs. The naming of the term Cembengan seems to be due to the influence of Chinese sugar experts as 'chefs' in determining the success of sugar production in the Colomadu sugar factory.

The Javanese people, as an agricultural society, play a more important role in the process of procuring industrial crops from planting, harvesting, and transporting sugarcane to the milling process. The process of milling sugarcane is a major event that involves hundreds of people, large machines, and many people's lives for quite a long time. Sugar cooking is a tough job and takes place once a year for a long period of time. For Chinese ethnic, spiritual support from their ancestors is needed throughout the Cembengan tradition.

Likewise, the Dutch-Indies colonial officials were immersed in Javanese culture when the Cembengan tradition took place. Documentation owned by Reksa Pustaka Mangkunegaran shows the involvement of the Dutch resident who was welcomed by Mangkunegara VII and his wife Gusti Timur to carry out the ritual of making offerings at the statue of Mangkunegara IV (the founder of the Colomadu sugar factory). European communities living in Java merge acculturation with various traditions in Java. It can be seen in Figure 2.

The Dutch colonial had a big significance in the presence of the Colomadu sugar factory. The influence of his proximity to the kingdom in Java yielded political and economic benefits. The DutchIndies sugar exports controlled the world market, the kingdom's wealth also increased. For the Dutch colonialists, the strategy adopted in order to be able to fuse with Javanese culture was to 'become Javanese' (Pemberton, 2018). The Javanese ritual ceremonies were complicated, long, and boring for a western culture that was carried out by the Dutch-Indies officials in the Surakarta residency to become part of the capital of local royal power in Java.

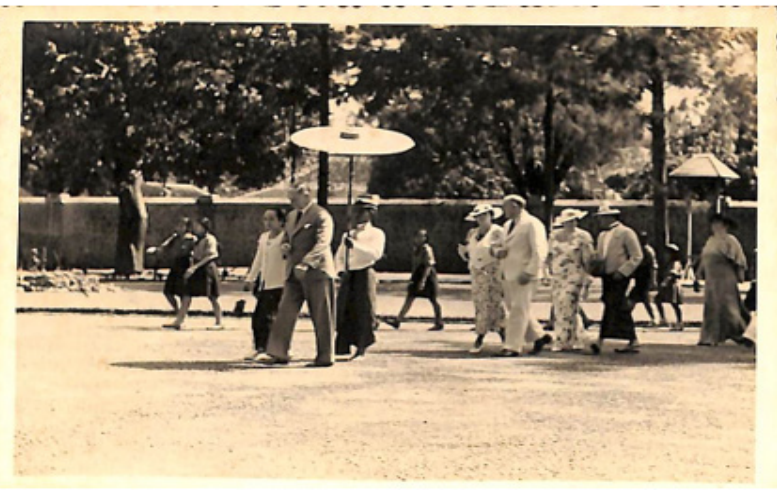

Figure 2 Resident of Surakarta and Administrators of the Colomadu Sugar Factory were Welcomed by Mangkunegara VII and His Wife before The Cembengan Ceremony

(Source: Reksa Pustaka Mangkunegara Library)

The statue of Mangkunegara IV was built in the Mangkunegara VII era as a tribute for the ancestors who had prepared the industrial space of sugar, which was first owned by natives (Figure 3 ). For the Javanese, the statue is not just a monument depicting their local leader but also a symbol of the sacredness that emerges after establishing the Colomadu sugar factory. The form of homage to the statue Mangkunegara IV in the Cembengan ceremony then passes on generation to the next generation as a dynamic form of cultural memory. Memory is not an unchanging legacy but a resource for making shared stories about the past (Rigney, 2018). Dutch Colonial involves in Cembengan tradition and participates in the following stages of the cultural traditions, including the tribute to the statue, which is believed by the Javanese community as a sanctity.

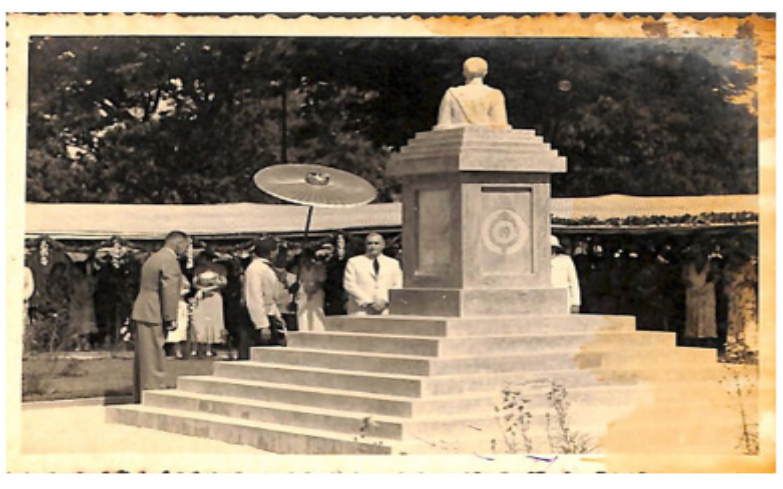

Figure 3 Dutch Resident and Mangkunegara VII Make Offerings at the Statue of Mangkunegara IV at Cembengan Rituals in 1937

(Source: Reksa Pustaka Mangkunegara Library) 
The Colomadu sugar factory employees believe that factory machines as objects that have spiritual power emerge through the process of forming traditions. Mangkunegara IV, as the local leader of the Javanese community, treated the giant machines from Europe as heirlooms. The courage to bring modernization through the investment of the Colomadu sugar factory in Mangkunegaran Palace was inseparable from the influence of the Dutch colonialists who had a political closeness to the king. The sugar factory, which was previously only owned by European investors, influenced Mangkunegara IV's thinking in investing in a modern way in sugar processing machines. The treatment of modern machinery as heirlooms was Mangkunegaran's strategy of caring for and safeguarding its investment. The Cembengan ceremony has been preserved for hundreds of years to maintain the belief in the Javanese people regarding the importance of these European-made machines. The emergence of the acculturation tradition in the Cembengan tradition is a cultural translation in a cultural space formed in an unequal structure between colonials, Chinese investors, and Javanese colonial society (Bhatia, 2012). However, the interpretive model of hybridity occurs subtly so that the Javanese feel like the original owner of the tradition.

The celebration of Cembengan seems to be the original tradition of Javanese culture, but there is a transcultural process behind it. The involvement of interests between Mangkunegaran, Chinese sugar experts, and the Dutch-Indies government helps shape the hegemony of the Javanese community to maintain sugar factories through the Cembengan tradition Colomadu sugar factory. The belief of the Javanese people in cosmological matters is exploited by the Dutch colonialists to protect their capital. Colonial is positioned in a higher position and becomes an important figure at the core of traditional ceremonies in Java. This process of 'invented tradition' presents something that seems to have been formed by traditions from the past but is actually formed recently (Hobsbawm \& Ranger, 1986; Farkas, 2016). The 'invented tradition' strategy is carried out by the Dutch colonialists, as the British treatment of their hegemonic African colonies where the position of white people higher than natives through slow penetration of local culture (Ranger, 2012). Colonized people do not realize that the traditions carried out continuously for hundreds of years in their culture are the formation of their colonizers.

The Colomadu sugar factory, which was originally built with the aim of being a space for the sugar industry in Java, actually involved various interests, which had an impact on cultural acculturation. The factory building, along with modern machinery, the monument statue of Mangkunegara IV, and the tomb of the founder of the factory, are signs of the emergence of linkages between culture, capital, and industrial space. The transcultural process that occurred through the interdependence of interests between Javanese, Chinese, and Dutch during the colonial period has led to a tradition of Cembengan celebration, which has cultural ties with the people of Colomadu.

This tradition is not only a human ritual with the cosmos but has a function as an economic and social activator for both sugar factory workers and community participants. Art and regional dances are accommodated through Cembengan, as well as the night markets as a trading and entertainment space for the people who animate the Colomadu sugar factory. The Cembengan tradition emerges from an invented tradition that produces a more meaningful culture for the ethnic groups involved. In the end, Cembengan not only belonged to and for the Javanese people, but also the transcultural between Javanese, Chinese, and Dutch colonial traditions. This tradition is not only a human ritual with the cosmos but has a function as an economic and social activator for both sugar factory workers and community participants. Art and regional dances are accommodated through Cembengan, as well as night markets as a trading and entertainment space for the people who animate the Colomadu sugar factory. The Cembengan tradition emerges from an invented tradition that produces a more meaningful culture for the ethnic groups involved. In the end, Cembengan not only belonged to and for the Javanese people, but also the transcultural between Javanese, Chinese, and Dutch colonial traditions.

\section{CONCLUSIONS}

The Cembengan ceremony is understood by the Javanese community as the original culture of their ancestors, which is carried out hereditary. This tradition is formed by the industrial space of the Colomadu sugar factory. After analyzing the history and symbolic meanings behind this tradition, it is found that Cembengan is an invented tradition process that the Javanese people accept. The meaning of the Cembengan is not just a Javanese ceremonial tradition of asking for safety before milling sugarcane. The Colomadu sugar factory involves the intersection of three nations with different cultures. This industrial space has formed transculturality so as to create the Cembengan ceremony.

The involvement of local Javanese leaders, Chinese investors, and Dutch colonial regulators contributes to the formation of this Cembengan ceremony. This tradition is easily accepted by the Javanese ethnic groups with similar beliefs to the Chinese ethnic group in respecting ancestral spirits before carrying out important events. The Cembengan is transculturation of Javanese, Chinese, and Dutch nations. It is begun with Dutch colonial capitalism that takes advantage of Javanese beliefs and ends up being a hereditary tradition to appreciate Chinese ancestry and the discipline of Javanese workers in the industrial space.

The analysis has proven that the transcultural process in industrial space has been going on since 
the colonial era. This strategy is once carried out by ancient societies without being rooted in origin. The transcultural process of the industrial space has produced a culture that is rich in meaning and ideas. This opens broader thinking to see the idea of cultural development currently taking place through a transcultural process. In the future, this can be developed as inspiration in the design of non-industrial spaces, both interior, and exterior, with reference to transcultural traditions.

\section{REFERENCES}

Ardhiati, Y., Damayanti, S., Anggita, D., Wibisono, A. I., Isna, R., Fajarwati, A. A. S., \& Lestariningsih, A. (2020). De Tjolomadoe: From cultural heritage to Industry 4.0. Journal of Applied Sciences and Advanced Technology, 3(1), 1-8. https://doi. org/10.24853/jasat.3.1.1-8.

Bhatia, S. (2012). Lost in translation: Cultural hybridity, acculturation, and human development: Commentary on de Haan. Human Development, 54(6), 400-407. https://doi.org/10.1159/000334730.

Birsyada, M. I., Wasino, W., Suyahmo., \& Joebagio, H. (2017). The business ethics of royal family: Mangkunegara IV, sufism and economy in Java. International Journal of Applied Business and Economic Research, 15(7), 33-57.

Farkas, I. (2016). Reconstructing tradition: The debate on "Invented Tradition" in the Japanese modernization. Acta Asiatica Varsoviensia, 29, 31-46.

Fauzi, H. I. R., Saddono, K., \& Rakhmawati, A. (2019). Symbolic meaning of food names in offerings at mantenan tebu traditional ceremony in Tasikmadu Karanganyar. Humanities and Social Sciences Reviews, 7(6), 470-476. https://doi.org/10.18510/ hssr.2019.7672.

Fauzi, H. I. R., Saddhono, K., \& Rakhmawati, A. (2020). The ritual "Mantenan Tebu" and its role as the promotion media of inherited Indonesian culture. Proceedings of $4^{\text {th }}$ International Conference on Arts Language and Culture (ICALC 2019). pp. 548-555. https://doi.org/10.2991/assehr.k.200323.063.

Hobsbawm, E., \& Ranger, T. (1986). The invention of tradition. Cambridge: Cambridge University Press. https://doi.org/10.2307/25142744.

Knight, G. R. (2000). The sugar industry of colonial Java and its global trajectory. South East Asia Research, 8(3), 213-238. https://doi. org/10.5367/000000000101297271.
Knight, G. R., \& Brown, C. (2016). Commanders and subalterns: Foreign capital, the sugar industry, farmer, and workers in rural Java, 1931-1959. Indonesia, 101, 85-102. https://doi.org/10.5728/ indonesia.101.0085.

Nugroho, P. S., Yuliastuti, N., Rukayah, Nugroho, R. S., Untung, R., \& Joko, C. (2020). Identifikasi pabrik gula sebagai industrial heritage di Jawa. Arsitektura: Jurnal Ilmiah Arsitektur dan Lingkungan Binaan, 18(1), 119-128. https://doi.org/10.20961/arst. v18i1.37936.

Pemberton, J. (2003). The specter of coincidence. In J. Siegel \& A. Kahin (Eds.), Southeast Asia over Three Generations: Essays Presented to Benedict R. O'G. Anderson (pp. 75-90). New York: Cornell University Press.

Pemberton, J. (2018). Jawa on the subject of Java. Yogyakarta: Matabangsa.

Pontjowolo, H. D. (1992). Tradisi slamatan giling (cembengan) PTP XV-XVI (Persero) P.G. Colomadu dan Tasikmadu tahun 1992. Surakarta: Reksa Pustaka Pura Mangkunegara.

Ranger, T. (2012). The invention of tradition in colonial Africa. In The Invention of Tradition (pp. 211-262). Cambridge: Cambridge University Press. https:// doi.org/10.1017/CBO9781107295636.006.

Rigney, A. (2018). Remembrance as remaking: Memories of the nation revisited. Nations and Nationalism, 24(2), 240-257. https://doi.org/10.1111/nana.12388.

Rosanawati, I. M. R. (2018). Makna simbolik upacara mantenan tebu pada tradisi Cembengan di Tasikmadu. Widya Sari: Jurnal Ilmiah Pendidikan, Sejarah, dan Sosial Budaya, 20(2), 11-18.

Sawega. (2000, June 2). Cembengan, Nayuban dan Obsesi Administratur. Kompas, pp. 28.

Trimerani, R. (2020). Tradisi selamatan cembengan dalam mewujudkan keteraturan sosial (Studi deskriptif di PG-PS Madukismo). Jurnal Sosial Humaniora, 11(2), 203-213. http://dx.doi.org/10.30997/jsh. v11i2.3199.

Wasino. (2005). Mangkunegara IV, Raja-Pengusaha, pendiri industri gula Mangkunegaran (1861-1881). Humaniora, 17(1), 31-37. https://doi.org/10.22146/ jh.v17i1.825.

Wasino.(2015). Modernisasibudaya politikMangkunegaran. Sejarah dan Budaya: Jurnal Sejarah, Budaya, dan Pengajarannya, 9(2), 257-263. 